\title{
NOP Receptor Ligands as Potential Agents for Inflammatory and Autoimmune Diseases
}

\author{
Elaine C. Gavioli ${ }^{1}$ and Pedro R. T. Romão ${ }^{2}$ \\ ${ }^{1}$ Laboratório de Farmacologia Comportamental, Programa de Pós-graduação em Desenvolvimento e Inovação \\ Tecnológica em Medicamentos, Departamento de Biofísica e Farmacologia, Centro de Biociências, \\ Universidade Federal do Rio Grande do Norte, 59072-970 Natal, RN, Brazil \\ ${ }^{2}$ Laboratório de Biologia Celular e Imunologia, Programa de Pós-Graduação em Ciências da Saúde, \\ Departamento de Ciências Básicas da Saúde, Universidade Federal de Ciências da Saúde de Porto Alegre, \\ 90050-170 Porto Alegre, RS, Brazil \\ Correspondence should be addressed to Pedro R. T. Romão, pedror@ufcspa.edu.br
}

Received 8 February 2011; Revised 31 August 2011; Accepted 24 September 2011

Academic Editor: Andreas Wyttenbach

Copyright ( 2011 E. C. Gavioli and P. R. T. Romão. This is an open access article distributed under the Creative Commons Attribution License, which permits unrestricted use, distribution, and reproduction in any medium, provided the original work is properly cited.

\begin{abstract}
Nociceptin/orphanin FQ (N/OFQ) is a seventeen-amino acid peptide that is the endogenous ligand of a G-protein-coupled receptor (NOP). Various immune cells express the precursor protein and secrete N/OFQ as well as display binding sites for this peptide. The functional capacity of NOP receptor was demonstrated in vitro and in vivo studies by the ability of N/OFQ to induce chemotaxis of immune cells, to regulate the expression of cytokines and other inflammatory mediators, and to control cellular and humoral immunity. In this context, N/OFQ could modulate the outcome of some inflammatory diseases, such as sepsis and autoimmune pathologies by mechanisms not clearly elucidated yet. In fact, human body fluid revealed increased levels of N/OFQ under sepsis, arthritis, and Parkinson's diagnose. Preclinical studies pointed to the blockade of NOP receptor signaling as successful in treating these experimental conditions. Further preclinical and clinical studies are required to investigate the potential of NOP ligands in treating inflammatory diseases.
\end{abstract}

\section{N/OFQ and NOP Receptor}

The peptide nociceptin/orphanin FQ (N/OFQ) was isolated for the first time in 1995 by two distinct research groups from rat [1] and porcine [2] brain extracts. N/OFQ is composed by seventeen amino acids residues, and this peptide was nominated nociceptin due to the hyperalgesic effects that it evokes after supraspinal administration [1]. The other name, orphanin FQ, was given by the Reinscheid's group due to the fact that this peptide displayed affinity to an orphan receptor-actually, this was one of the first well-experienced cases of reversal pharmacology; while $\mathrm{F}$ and $\mathrm{Q}$ were used to discriminate the amino acids phenylalanine from the $\mathrm{N}$ terminal and glutamine located in the C-terminal position [2].

$\mathrm{N} / \mathrm{OFQ}$ is a neuropeptide sharing sequence homology with classical opioid peptides, but with a distinct pharmacological profile. N/OFQ was being considered an opioid-like peptide, since it is structurally related to endogenous opioids, particularly dynorphin $\mathrm{A}$; however, N/OFQ does not bind to classical opioid receptors [2]. Additionally, N/OFQ is the endogenous ligand for the N/OFQ peptide (NOP) receptor (nominated before as opioid receptor like-1, abbreviated as ORL-1), which is closely related to the opioid receptor family, but does not bind opioid ligands [3]. NOP, similar to the opioid family, is a receptor coupled to a G-protein. Thus, the activation of the N/OFQ signaling via NOP receptor can lead, among other effects, to inhibition of adenylate cyclase, blockade of $\mathrm{Ca}^{2+}$, and opening of $\mathrm{K}^{+}$channels (for a review, see [4]), as described in details in Section 5.

The N/OFQ peptide precursor (ppN/OFQ) and NOP receptor are widely expressed in the nervous system as well as in peripheral organs and the immune system. In the central nervous system, of particular interest is the expression of NOP receptor in the forebrain, including cortical areas, olfactory regions, the thalamus, and a variety of limbic structures, 
such as the hippocampus, the amygdaloid complex, and in several nuclei of the hypothalamus, that are involved in the processing of emotional stimuli. Some brainstem areas, as the periaqueductal gray, on serotoninergic and noradrenergic nuclei (i.e., raphe complex and locus coeruleus), and several sensory and motor nuclei also express NOP receptors (for a review, see [5]). In contrast to the expression of NOP receptors, the distribution of the ppN/OFQ mRNA is almost limited to the limbic areas $[6,7]$.

In the periphery, NOP receptor has been detected in the peripheral nervous system and several organs, such as rat intestine and vans deferens [8], retina [9], heart [10], porcine gastrointestinal tract and kidney [11], and several guinea-pig ganglia. However, one of the principal locations of the NOP receptor in the periphery is the immune system. mRNA transcripts for the NOP receptor have been detected in mouse splenic lymphocytes $\left(\mathrm{CD} 4^{+}, \mathrm{CD}^{+}, \mathrm{CD}^{-}\right.$, and $\left.\mathrm{CD} 8^{-}\right)$[12]. In the human immune system, NOP receptors are also expressed in lymphocytic B and T-cell lines, monocytic cell lines, circulating lymphocytes, and monocytes $[13,14]$. Taken together, this wide central and peripheral distribution of NOP expression may explain the broad spectrum of biological actions of this peptidergic system. In fact, in vivo, experimental studies have demonstrated that N/OFQ modulates a variety of biological functions, such as nociception $[1,2]$, food intake [15], learning and memory processes [16], spontaneous locomotor activity [2], rewarding actions of opioids [17] and ethanol [18], and responses to stress and anxiety [19]. Peripheral effects, such as hypotension, bradycardia [20], diuresis [21], inhibition of gastrointestinal [11] and airway [22] motility, and/or some reflexes such as coughing [23] and the micturition reflex [24] have also been reported for N/OFQ. Most recently, the effects of N/OFQNOP receptor system in modulating immune functions have received particular attention, in special its involvement in sepsis, inflammatory, and autoimmune diseases. In this review, we focus on summarizing the experimental evidence that suggests an important role played by this peptidergic system in the modulation of the immune functions, and we highlight the potential therapeutic effects of NOP ligands in the treatment of diseases which involve immune responses.

\section{The Relationship between N/OFQ and Immune System}

Neuropeptides have been described as important source of immunoregulatory molecules [25-27]. In this line, several evidence suggests that N/OFQ-NOP pathway may act as a potent regulatory during immune response.

In 1995, Halford and colleagues [12] reported for the first time the expression of NOP receptors in mouse lymphocytes, while at the same year, Wick et al. [14] described the expression of NOP receptor mRNA in human peripheral blood lymphocytes and lymphocytic cell lines. In agreement, in 1998, Peluso and colleagues [13] detected the expression of mRNA NOP receptor in the human normal circulating lymphocytes and also in monocytes. Still in 1998, Pampusch et al. [28] demonstrated that NOP receptors are also expressed in the porcine immune cells and, in 2000, the same research group reported the expression of NOP receptor and ppN/OFQ mRNA in porcine lymphoid tissue, such as thymus, lymph nodes, spleen, and freshly isolated splenocytes [29]. Later, it was demonstrated that high-affinity binding sites for N/OFQ are distributed in human mononuclear [30] and polymorphonuclear leukocytes [31, 32]. Additionally, the incubation of human neutrophils with N/OFQ elicited intracellular signaling which was mimicked by the NOP synthetic agonist, Ro 64-6198, thus reinforcing that NOP receptors are present and functional in human neutrophils [32].

In 2002, for the first time, it was reported that the peripheral blood mononuclear cells transcribe ppN/OFQ [30]. Additionally, it was reported that $\mathrm{N}$-formyl-methionineleucine-phenylalanine-(fMLP-) stimulated polymorphonuclear neutrophils rapidly secrete N/OFQ by exocytosis, indicating that at least in neutrophils this neuropeptide is stored in preformed vesicles rather than de novo synthesized [32]. Nowadays, it is accepted that numerous immune cells were found to secrete N/OFQ, thus pointing to these inflammatory cells as a source of N/OFQ. Importantly, several inflammatory mediators including bacterial products (i.e., lipopolysaccharide, LPS) and cytokines could modulate both the transcription of ppN/OFQ mRNA and its protein expression [33, 34]. Therefore, N/OFQ seems to act as a paracrine, autocrine, and/or endocrine immunomodulator, since activated immune cells led to the induction of NOP receptor mRNA, and the same activated cells were able to express N/OFQ.

Based on in vitro and in vivo studies, many biological actions were reported for N/OFQ and NOP receptor system in modulating immune functions. In vitro studies have shown that N/OFQ evokes chemotaxis of polymorphonuclear [31] and human monocytes [35], and when injected in murine air pouches (an animal model to study leukocyte infiltration in vivo), N/OFQ elicits leukocyte infiltration in a concentration-dependent manner [31].

Further studies aiming to investigate the mechanisms by which N/OFQ stimulates chemotactic responses suggest that these effects are mediated by NOP receptors, since the selective blockade of NOP receptors prevent these actions [35]. It was found also that N/OFQ-stimulated polymorphonuclear neutrophils infiltration was inhibited by treating mice with a synthetic analog of the aspirin-triggered lipid mediator 15epi-lipoxin $\mathrm{A}_{4}$ [31]. Taken together, these data suggest that N/OFQ, via activation of NOP receptor signaling, acts as a potent chemoattractant, possibly due to the involvement of arachidonic acid products.

Evidence from the literature also suggests that N/OFQNOP receptor system plays a role in regulating chemoattractant responses of leukocytes through chemokine suppression [36]. Chemokines are now known to be involved in mediating chemotaxis, integrin activation and leukocyteendothelial cell interactions, leukocyte degranulation, and release of inflammatory mediators and angiogenesis ([37, 38]; for a review, see [39]). Kaminsky and Rogers [36] reported that N/OFQ suppresses the production of CCL2/MCP-1 and CCL5/RANTES chemokine protein in both primary $\mathrm{CD} 14^{+}$human monocytes and monocyte-like 
cell lines. However, this suppression does not seem to be at the level of transcription, as N/OFQ treatment did not alter the mRNA levels for these chemokines in monocytes.

A series of data support a modulatory effect of N/OFQ under cellular immunity, as summarized below. Peluso and colleagues [40] demonstrated that in vitro N/OFQ could decrease the proliferative response of human peripheral blood mononuclear cells stimulated with phytohemagglutinin. Miller and Fulford [34] have found that both the IL-2 production and $\mathrm{T}$ lymphocyte proliferation induced by the mitogen Con A were inhibited by N/OFQ.

Elegant data described by researchers from McLeod's Laboratory have elucidated the mechanism by which N/OFQ modulates human T-cell response. First, the authors showed that N/OFQ inhibits the proliferative response of $\mathrm{T}$ cells activated by staphylococcal enterotoxin B (SEB) presented by Chinese Hamster Ovary (CHO) cells transfected with human HLA DR4 and CD80 [41], and in a subsequent work, they showed that the suppressive effect of N/OFQ on the T-cell proliferation could be blocked by the NOP receptor antagonist UFP-101, an anti-CD80 antibody, an inactivator of transforming growth factor- $\beta$ (TGF- $\beta$ LAP), L-NAME, and L-NMMA (both NOS inhibitors). They also have shown that N/OFQ induces the expression of the immunosuppressive modulator indoleamine 2,3-dioxygenase (IDO) [42]. In view of the factors modulating IDO expression, it was suggested that N/OFQ decreases T-cell proliferation through IDO expression by a mechanism involving IFN- $\gamma$, TGF- $\beta$, prostaglandin and nitric oxide.

The ability of N/OFQ-NOP receptor system in modulating humoral immunity was also described in the literature. Recently, it has been demonstrated that N/OFQ, added in vitro to murine spleen cells at picomolar concentrations, caused a significant suppression of antibody formation against sheep red blood cells, which was reversed by NOP antagonists [43]. In addition, N/OFQ given in vivo by osmotic pump for $48 \mathrm{~h}$ suppressed the capacity of spleen cells cultured ex vivo to produce anti-sheep red blood cell antibody [43]. These studies showed that N/OFQ directly inhibits an adaptive immune response, that is, antibody production, both in vitro and in vivo.

In agreement with the evidence for an immunosuppressive effect evoked by N/OFQ, Du and colleagues [44] have shown that in normal rats the intracerebroventricular administration of N/OFQ, at nmol doses, reduced the NK cell activity. However, in rats under surgical trauma, N/OFQ antagonised the immune function depression, and this anti-immunosuppression evoked by N/OFQ was completely reversed by the pretreatment with the antisense oligonucleotide to NOP receptor mRNA [44]. Taken together, a growing body of evidence suggests a complex role for N/OFQ in modulating, by inhibiting or activating, immune functions depending on the nature of the stimuli.

\section{The Involvement of Inflammatory Mediators in N/OFQ-Evoked Immune Actions}

It is well established that regulation of immune and inflammatory responses depends on cytokines signaling. Therefore, it is expected that N/OFQ evokes immune responses as a result of the modulation of cytokine activity or expression. However, it is possible that the altered expression of cytokines is due to the NOP receptor signaling-induced production of regulatory mediators which, in turn, lead to altered levels of cytokines (for a review, see [39]).

There is no consensus regarding the role of N/OFQ on inflammatory and immune responses. In fact, Goldfarb and colleagues [45] demonstrated that in C57BL/6J mice the intraperitoneal injection of N/OFQ $(55 \mathrm{nmol} / \mathrm{kg}) 30 \mathrm{~min}$ before challenge with Staphylococcal enterotoxin A (SEA, $5 \mu \mathrm{g}$ ) caused a significant increase in levels of spleen TNF- $\alpha$ and IFN- $\gamma$ mRNA, without causing any significant effects on IL- $1 \beta$ and IL-2 mRNA levels. Moreover, mice lacking the N/OFQ precursor gene showed diminished TNF- $\alpha$ and IFN- $\gamma$ transcripts in the spleen in response to SEA challenge, suggesting that N/OFQ system can exacerbate the immune function.

By contrast, following the induction of trauma in rats, Zhao and colleagues [46] found typical robust increases in both TNF- $\alpha$ and IL- $1 \beta$ transcripts in peritoneal macrophages, but when N/OFQ was intracerebroventricularly administered, both TNF- $\alpha$ and IL- $1 \beta$ expression was attenuated in these cells. Additionally, N/OFQ immunoreactive cells and mRNA for NOP receptor were significantly reduced after trauma in cerebral cortex, hippocampus, and hypothalamus of rats [46]. Still under traumatic stress, high levels of IL- $1 \beta$ transcript in hippocampus were antagonised by icv administration of $\mathrm{N} / \mathrm{OFQ}$, and these effects were reversed by the treatment with an NOP receptor antagonist [47], thus suggesting that the effects of N/OFQ in the cytokines expression could depend on the tissues, pretreatment time, dose and via of N/OFQ administration, and nature of stimuli [39]. Obviously, further studies at this point should be performed in order to give additional information about the role played by the N/OFQ-NOP receptor system in the modulating cytokines expression.

It is worthy of mentioning that the inflammatory process is a necessary step for induction of protective immunity and to contain the infections, but can also lead to dangerous effects, if uncontrolled. Hence, an imbalance between proinflammatory and anti-inflammatory mediators, between Th1/Th17 effector cells and $\mathrm{T}$ regulatory cells may result in hyperinflammatory or autoimmune diseases. Considering the bidirectional relationship between the N/OFQ-NOP and the immune system, it is possible that NOP receptor signaling modulates the outcome of some inflammatory diseases including sepsis, autoimmunity, and possibly the transplantation rejection, a condition not investigated yet.

\section{N/OFQ-NOP Receptor System and Inflammatory and Autoimmune Diseases}

The complex syndrome of sepsis is characterized by impaired recruitment of neutrophils, inability of the immune system to limit bacterial spread during an ongoing infection and systemic inflammation associated with deleterious accumulation of neutrophils in vital organs, especially the lung that 
culminates in multiple organ failure [48-50]. The systemic inflammatory response syndrome (SIRS), hallmark sign of sepsis, is characterized by a systemic inflammatory response with massive release of proinflammatory cytokines such as TNF- $\alpha$, IL- $1 \beta$, chemokines, nitric oxide, leukotrienes, reactive oxygen species $[51,52]$. This response is counterregulatory by a compensatory anti-inflammatory response syndrome (CARS) through the secretion of inhibitory molecules such as IL-10 and TGF- $\beta$. It has been suggested that in septic patients a delicate balance between the pro and anti-inflammatory mediators are decisive to the outcome of disease [53], since the proinflammatory phase is necessary for both the recruitment of neutrophils and induction of microbicidal activity but also responsible for the failure of neutrophils migration to the infectious focus. In addition, it may be related to subsequent immunosuppression $[49,54]$.

Using the caecal ligation and puncture (CLP) model of sepsis, our group have demonstrated that the administration of the NOP receptor antagonist UFP-101, immediately after surgery, promoted a significantly reduction on mortality rate of septic rats compared with CLP-untreated rats [55]. In this study, we observed that the protective dose of NOP antagonist was able to prevent the massive influx of inflammatory cells into both the lung and bacterial dissemination. These protective effects were associated with significant decrease in plasmatic levels of TNF- $\alpha$, IL-1 $\beta$, and CCL2 [55]. It should be mentioned that this beneficial effect of UFP-101 was evident after a single drug injection after induction of CLP, suggesting that the N/OFQ-NOP system plays an important role in modulating the early phases of the septic process. The molecular mechanisms by which the NOP receptor antagonist, UFP-101 have protected septic rats are under investigation by our group. In our study, we did not evaluate the role of nitric oxide and other regulatory molecules such as programmed death-1 (PD-1)/PD-1 ligands, TGF- $\beta$, and CLTA-4 (Cytotoxic T-lymphocyte antigen 4). Although we have detected a decreased number of bacteria in the blood, it was not investigated whether NOP antagonist modulates directly or indirectly the bactericidal activity of neutrophils.

Additional data have supported the idea that high levels of N/OFQ in septic patients may contribute to its pathogenesis. Despite the small size of the sample, it was found that septic patients who died within 30 days $(n=4)$ displayed higher N/OFQ plasmatic levels compared with survivors ( $n$ = 17) [56]. However, when evaluating the role of N/OFQNOP receptor system in a complex event such as sepsis, we should be aware of the broad range of effects evoked by NOP receptor signaling, that contribute to the septic condition, such as impairment of cardiovascular performance and tissue perfusion, beside the immune responses herein discussed (for a review see [57]). Very recently, Stamer and colleagues [58] have shown that peripheral blood cells from patients with sepsis had higher N/OFQ and lower ppN/OFQ mRNA expression than healthy controls. Again, these observations suggest the involvement of the NOP-N/OFQ system in inflammation and impaired immune function in sepsis.

Corroborative data showing the involvement of N/OFQNOP system in the physiopathology of other immune disturbances have been described. In this regard, Fiset and colleagues [32] found high levels of N/OFQ in the synovial fluid but not in the plasma of patients with arthritis. In view of the presence of N/OFQ and polymorphonuclear cells accumulation in the inflammatory synovial cavity of arthritic patients, further studies are imperative to investigate the involvement of N/OFQ-NOP receptor at the beginning of the inflammatory process.

Using a mouse model of bowel disease induced by the injection of dextran sulfate sodium, Kato and colleagues [59] demonstrated that both the inflammatory response and severity of disease were associated with the upregulation of N/OFQ expression. Furthermore, NOP knockout mice did not develop colitis, thus indicating the participation of N/OFQ in disease [59]. Regarding the histopathological findings, the authors found that the number of T lymphocytes ( $T$ $\mathrm{CD}^{+}$and $\mathrm{T} \mathrm{CD8} 8^{+}$), B lymphocytes, macrophages, and neutrophils present in the colonic mucosa of dextran sulphate sodium-treated NOP-deficient mice was significantly lower than the number of those found in wild-type animals.

Concerning Parkinson's disease, the second most common age-associated progressive neurodegenerative disorder, the inflammation, oxidative stress, and microglia-mediated neurotoxicity of dopaminergic neurons in the substantia nigra are considered the hallmark of disease [60-63]. Some findings for neuroinflammatory mechanisms leading to the immunopathology of Parkinson's disease include microgial activation, secretion of TNF- $\alpha$, IL- $1 \beta$, IL-2, IL- 6 , and CCL5, antibody against different components of dopaminergic neurons, expression of inducible nitric oxide synthase, astrogliosis, shift to Th1 phenotype, increased number of activated $\mathrm{T}$ cells, and other inflammatory markers [60-62, 64-69]. Several preclinical studies reported by Professor's Morari's group have suggested the participation of N/OFQ in the physiopathology of Parkinson's disease [70-74]. Interestingly, an enhancement of N/OFQ expression and release in 6-hidroxydopamine hemi-lesioned rats was detected in the lesioned substantia nigra compared with the unlesioned, indicating that parkinsonism may be associated with overactivation of NOP receptor signaling [71]. Furthermore, the pharmacological blockade of NOP receptor signaling attenuates parkinsonian-like behavior in 6-hydroxydopamine hemi-lesioned, haloperidol, and reserpine-treated rodents, whereas deletion of the NOP receptor gene conferred mice protection from these symptoms [71, 74, 75]. Corroborating to the view that N/OFQ-NOP receptor system plays an important role in Parkinson's disease, very recently, Marti and colleagues [76] found increased levels of N/OFQ in the cerebrospinal fluid of parkinsonian patients compared with nonparkinsonian.

\section{Mechanisms Underlying N/OFQ-Induced Immune Regulation}

The OFQ/N system modulates many functions in a variety of immune cells including monocytes, macrophages, neutrophils, mast cells, and lymphocytes by a mechanism not clearly elucidated yet. Table 1 summarizes some of these functions, the participation of N/OFQ in the neuroimmune 
TABLE 1: Mechanisms underlying some immunoregulatory activities triggered by NOP receptor activation.

\begin{tabular}{|c|c|c|c|}
\hline $\begin{array}{l}\text { Biological effects related to N/OFQ or its } \\
\text { interaction in the neuroimmune axis }\end{array}$ & Mechanisms & Animal conditions or cell type & Ref \\
\hline $\begin{array}{l}\text { Bacterial products (LPS) and } \\
\text { inflammatory cytokines (IL- } 1 \beta \text { and } \\
\text { TNF- } \alpha \text { ) increase the expression of } \\
\text { N/OFQ in astrocytes }\end{array}$ & $\begin{array}{l}\text { Dependent on ERK, p38 MAPK, and } \\
\text { NF- } \kappa \text { B activation }\end{array}$ & Primary rat astrocytes culture & {$[33]$} \\
\hline $\begin{array}{l}\text { LPS induce N/OFQ expression in dorsal } \\
\text { root ganglion (DRG) neurons }\end{array}$ & $\begin{array}{l}\text { The complex TLR-4-MD-1 seems to be a } \\
\text { functional receptor of neurons for LPS }\end{array}$ & DRG neurons obtained from mice & {$[77]$} \\
\hline $\begin{array}{l}\text { N/OFQ induces vasodilatation and } \\
\text { hyperemia in acutely inflamed rat knees }\end{array}$ & $\begin{array}{l}\text { Dependent of mast cells, and circulating } \\
\text { leukocytes, which produces } \\
\text { proinflammatory factors that stimulate } \\
\text { capsaicin-sensitive nerves leading to } \\
\text { release of SP, CGRP and VIP }\end{array}$ & $\begin{array}{l}\text { Anesthetized rats (kaolin/carragee } \\
\text { an arthritis model) }\end{array}$ & {$[78]$} \\
\hline $\begin{array}{l}\text { Increased vascular permeability in rat } \\
\text { skin by local application of nociceptin }\end{array}$ & Histamine released from mast cells & $\begin{array}{l}\text { Wistar rats, peritoneal mast cells } \\
\text { isolated }\end{array}$ & {$[79]$} \\
\hline $\begin{array}{l}\text { N/OFQ i.v. injection induces } \\
\text { hypotension, vasodilatation, vascular } \\
\text { permeability, leukocytes rolling, and } \\
\text { adhesion }\end{array}$ & $\begin{array}{l}\text { Vasodilation and inflammation } \\
\text { dependent, of histamine released by mast } \\
\text { cells }\end{array}$ & Wistar rats & {$[80]$} \\
\hline $\begin{array}{l}\text { N/OFQ elicits in mice itch and } \\
\text { leukotriene } \mathrm{B}_{4} \text { production }\end{array}$ & Not clear & ICR mice, keratinocytes from mice & {$[81]$} \\
\hline $\begin{array}{l}\text { N/OFQ induces chemotaxis of } \\
\text { neutrophils in vitro and leukocytes } \\
\text { recruitment in vivo }\end{array}$ & $\begin{array}{l}\text { The chemotaxis were } \mathrm{Ca}^{2+} \text { independent, } \\
\text { and leukocytes infiltration into air } \\
\text { pouches cavities were inhibited by } \\
\text { 15-Epi-Lipoxin } \mathrm{A}_{4} \text { treatment }\end{array}$ & $\begin{array}{l}\text { Human PMN-isolated and murine } \\
\text { air pouches model }\end{array}$ & {$[31]$} \\
\hline $\begin{array}{l}\text { Human neutrophils secrete preformed } \\
\text { N/OFQ upon degranulation induced by } \\
\text { microbial-derived } N \text {-formylated protein }\end{array}$ & $\begin{array}{l}\text { N/OFQ prevents cAMP elevation in } \\
\text { fMLP-stimulated PMNs acting as an } \\
\text { activating signal }\end{array}$ & Human neutrophils & {$[32]$} \\
\hline $\begin{array}{l}\text { NOP-deficient mice developed attenuated } \\
\text { colitis when orally treated with dextran } \\
\text { sulfate sodium }\end{array}$ & $\begin{array}{l}\text { Decreased expression of MadCAM-1 and } \\
\text { significant reduction in the number of } \\
\text { lymphocytes, macrophages and } \\
\text { neutrophils in colonic mucosa }\end{array}$ & $\begin{array}{l}\text { NOP deficient and wild-type } \\
\text { C57BL6 mice }\end{array}$ & {$[59]$} \\
\hline $\begin{array}{l}\text { Pharmacological blockade of NOP } \\
\text { receptor decreases rate mortality and } \\
\text { systemic inflammation in septic rats }\end{array}$ & $\begin{array}{l}\text { Control of bacteria spread (peritoneal } \\
\text { cavity and blood) and decreased lung } \\
\text { infiltration and serum levels of TNF- } \alpha \text {, } \\
\text { IL- } 1 \beta \text {, and CCL } 2\end{array}$ & Rats subjected to CLP & {$[55]$} \\
\hline $\begin{array}{l}\text { N/OFQ decreases SEB-activated T-cell } \\
\text { proliferation }\end{array}$ & $\begin{array}{l}\text { Induction of active IDO expression in T } \\
\text { cells by a mechanism involving IFN- } \gamma \text {, } \\
\text { TGF- } \beta \text {, prostaglandin, and nitric oxide }\end{array}$ & SEB-activated $\mathrm{CD} 4^{+} \mathrm{T}$ cells & {$[42]$} \\
\hline $\begin{array}{l}\text { Modulation of genes transcription } \\
\text { involved in the neuroimmune axis } \\
\text { functions }\end{array}$ & $\begin{array}{l}\text { N/OFQ induces cell signaling via several } \\
\text { intracellular pathways leading to MAP } \\
\text { kinase activation, } \mathrm{PKC} \text { activation, } \mathrm{NF} \kappa \mathrm{B} \\
\text { nuclear translocation, and hence gene } \\
\text { transcriptions }\end{array}$ & $\begin{array}{l}\text { Human neuroblastoma SH-SY5Y } \\
\text { cells, CHO transfected cells }\end{array}$ & {$[82-85]$} \\
\hline
\end{tabular}

CCL2: chemokine (C-C motif) ligand 2; CGRP: calcitonin gene-related peptide; CLP: cecal ligation and puncture; ERK: extracellular signal-regulated kinase; fMLP: formyl-methionyl-leucyl-phenylalanin; IDO: indoleamine 2,3-dioxygenase; MAdCAM-1: mucosal addresin cell adhesion molecule-1; MAPK: mitogenactivated protein kinase; MD-1: myeloid differentiation protein-1; NF $\kappa$ B: nuclear factor Kappa B; PMN: polymorphonuclear neutrophil; SP: substance P; TLR4: toll-like receptor 4; VIP: vasoactive intestinal peptide.

axis, and the mechanisms underlying some immunoregulatory activities triggered by NOP receptor activation.

NOP receptor together with the classical opioids $(\mu, \kappa, \delta)$ receptors belongs to the G-protein-coupled receptor (GPCR) family, which plays a vital role in the transduction of signals regulating several effectors. Regarding to $\mathrm{N} / \mathrm{OFQ}$, some authors have described that the NOP activation by its natural ligand or agonists induces the activation of $\mathrm{K}^{+}$conductance and inhibition of voltage-gated $\mathrm{Ca}^{2+}$ channels and either augments (via activated $\alpha$-subunit of Gs class of G-protein) or decreases (via the activated form of the $G_{i} / G_{0}$ ) cAMP formation in a variety of cells including immune cells $[1,2,4$, 86-88]. N/OFQ also induces stimulation of phospholipase C (via $\alpha$-subunit of $\mathrm{G}_{\mathrm{q}}$ ), which leads to $1,4,5$-triphosphate $\left(\mathrm{IP}_{3}\right)$ and diacylglycerol production and also to $\mathrm{Ca}^{2+}$-dependent protein kinase $\mathrm{C}(\mathrm{PKC})$ activation (for a review, see $[83,89$, 90]). It was also demonstrated that in $\mathrm{CHO}$ cells the type of G-protein involved in PKC activation by N/OFQ were a $G_{i / o}$ 
G-protein [91]. Moreover, N/OFQ modulates extracellular signal-regulated kinase (ERK), p38, c-Jun N-terminal Kinase (JNK) isoforms of mitogen-activated protein kinase (MAPK) $[82,90,92,93]$, and the transcription of a variety of genes involved in immune and inflammatory responses $[83,94]$. It had been suggested that the signal transducer and activator of transcription (STAT3) may be involved in the transduction of NOP signaling [90, 95].

Considering the glia-immune cells communication, it was demonstrated that LPS, IL- $1 \beta$, and TNF- $\alpha$ increase the levels of N/OFQ mRNA and immunoreactivity in rat astrocytes in culture by a mechanism dependent of the activation of ERK 1/2, p38 MAP kinases and the transcription factor CREB. It was demonstrated that $\mathrm{NF} \kappa \mathrm{B}$ pathway appears to be involved in the induction of N/OFQ transcription by LPS [33]. N/OFQ has been shown to cause I $\kappa$ B kinase (IKK) phosphorylation and $\mathrm{I} \kappa \mathrm{B}$ degradation in SH-SY5Y human neuroblastoma cells [84]. Recently, Donica and colleagues [85] showed that N/OFQ increases the nuclear translocation, binding to DNA, and activation of transcription. Hence, the activation of $\mathrm{NF} \kappa \mathrm{B}$ by $\mathrm{N} / \mathrm{OFQ}$ may be critical for many immune functions.

\section{Relationship between N/OFQ and Classical Opioids in the Regulation of Immune Functions}

As commented above, N/OFQ belongs to the opioid family, but despite the structural homology between ligands and receptors, there is no evidence that N/OFQ activates opioid receptors, neither classical opioid ligands activate NOP receptor [83]. Importantly, NOP and ppN/OFQ mRNA are found expressed constitutively in distinct cells of the immune system $[1,45,96]$, while kappa opioid receptors are constitutively expressed in lymphocytic cells [97], but this is not the case of mu and delta opioid receptors $[13,98]$. Additionally, beta-endorphin and dynorphin are expressed and secreted by immune cells, including T cells, and upregulated in these cells by various stimuli [99-103]. It is wellknown that cytokines, mediators typically released from immune cells, are potent regulators of mu-opioid receptor gene expression. In fact, mu receptors are not constitutively expressed in immune cells, but these receptors are upregulated in $\mathrm{T}$ cells and $\mathrm{B}$ cells following pretreatment with interleukin 4 (IL-4) and TNF$\alpha[104,105]$. Thus, suggesting a putative role of classical opioids in the regulation of the immune functions.

It is well documented that opioid peptides cause immunosuppressive effects in some assays and stimulatory actions in others [106-108], however, morphine, which is a preferred mu receptor agonist, generally has been found to be immunosuppressive in a variety of assays [109].

The current review has showed that N/OFQ has immunomodulatory actions, by stimulating or inhibiting the immune system. However, little information is still available in the literature regarding the relationship between N/OFQ and classical opioid systems. Anton and colleagues [43] showed that N/OFQ inhibits antibody formation in a naloxone-insensitive manner, thus suggesting that N/OFQ effects, at least in this particular case, are not mediated by classical opioid receptors [43]. Another recent evidence that show no interaction between N/OFQ-NOP receptor system and the classic opioid system is coming from a clinical study, in which patients suffering from cancer who were taking opioid medication (morphine or equivalents) did not display any significant alterations in NOP and ppN/OFQ expression compared with those who did not receive opioids pretreatment [58]. These observations suggest that, despite the immunosuppressive effects of opioid in addicted patients [110], the mechanisms by which classical opioids affect immune functions, especially in the periphery, did not seem to be related to the N/OFQ-NOP receptor system.

Considering the expression of classical opioids (ligands and receptors) and N/OFQ-NOP receptor in the central nervous system, beside the immune cells, a putative neuroimmune cross-talk could be suggested. It is accepted that classical opioids depress the immune function, due to the activation of the hypothalamic-pituitary-adrenal axis (HPA), thus increasing corticoid hormone production [111]. Some studies have suggested that N/OFQ activates the HPA axis. In fact, intracerebroventricular injection of N/OFQ in rats led to increased plasma adrenocorticotropic hormone (ACTH) concentrations [112] and corticosterone [113] under resting conditions. N/OFQ administered to rats under mild stress enhanced the raised ACTH response to stress and prolonged the higher concentrations of corticosterone, while UFP-101, an NOP receptor antagonist, significantly attenuated plasma ACTH and corticosterone compared to saline injection in LPS-treated rats [114]. However, under a more stressful stimulus, such as restraint, central injection of N/OFQ did not affect the elevated plasma concentrations of ACTH or corticosterone [112].

Additionally, Leggett et al. [114] found increased corticotrophin-releasing factor (CRF) and corticotrophic pro-opiomelanocortin (POMC; a protein precursor of ACTH, beta-endorphin, and Met-enkephalin) mRNA into the parvocellular paraventricular nucleus expression due to LPS challenge compared to non-LPS treated rats. Additionally, the intracerebroventricular administration of UFP101 in LPS-treated rats was associated with increased POMC mRNA expression $4 \mathrm{~h}$ after injection and a clear trend towards increased parvocellular CRF mRNA. Taken together, a neuroimmune cross-talk between the N/OFQNOP receptor and classical opioid systems seems to be occurring and could be involved in the modulation of the immune responses.

\section{Concluding Remark}

In conclusion, there is no consensus regarding the role of N/OFQ-NOP receptor system in modulating inflammatory and immune responses. In fact, some studies have shown that N/OFQ is able to evoke chemotaxis, inhibit cellular and humoral immunity, and increase or suppress the expression of proinflammatory cytokines, such as TNF- $\alpha$ and IFN$\gamma$. Certainly, these immunological effects evoked by this peptidergic system make the NOP receptor an attractive 
therapeutic target for the treatment of inflammatory diseases, such as sepsis, rheumatoid arthritis, colitis, and other immunological disturbances. Interesting enough, preclinical findings from animal models of sepsis, colitis, and Parkinson pointed to the blockade of NOP receptor signaling as beneficial to diseases' outcome. Additional support to the involvement of N/OFQ in mediating these pathologies was found in human body fluids from patients suffering from sepsis, arthritis, and Parkinson, which displays increased N/OFQ levels. Thus, showing the vast range of immune functions evoked by N/OFQ, an extensive research in basic and clinical sciences is mandatory to further investigate the potential therapeutic effects of NOP ligands in the treatment of inflammatory diseases.

\section{Acknowledgment}

The authors would like to thank the Brazilian National Council Research for the financial support.

\section{References}

[1] J. C. Meunier, C. Mollereau, L. Toll et al., "Isolation and structure of the endogenous agonist of opioid receptor-like ORL1 receptor," Nature, vol. 377, no. 6549, pp. 532-535, 1995.

[2] R. K. Reinscheid, H. P. Nothacker, A. Bourson et al., "Orphanin FQ: a neuropeptide that activates an opioidlike G protein-coupled receptor," Science, vol. 270, no. 5237, pp. 792-794, 1995.

[3] B. M. Cox, C. Chavkin, M. J. Christie et al., "Opioid receptors," in The IUPHAR Compendium of Receptor Characterization and Classification, D. Girdlestone, Ed., pp. 321-333, IUPHAR Media, London, UK, 2nd edition, 2000.

[4] D. G. Lambert, "The nociceptin/orphanin FQ receptor: a target with broad therapeutic potential," Nature Reviews Drug Discovery, vol. 7, no. 8, pp. 694-710, 2008.

[5] C. Mollereau and L. Mouledous, "Tissue distribution of the opioid receptor-like (ORL1) receptor," Peptides, vol. 21, no. 7, pp. 907-917, 2000.

[6] A. Boom, C. Mollereau, J. C. Meunier et al., "Distribution of the nociceptin and nocistatin precursor transcript in the mouse central nervous system," Neuroscience, vol. 91, no. 3, pp. 991-1007, 1999.

[7] C. R. Neal Jr., A. Mansour, R. Reinscheid, H. P. Nothacker, O. Civelli, and S. J. Watson, "Localization of orphanin FQ (nociceptin) peptide and messenger RNA in the central nervous system of the rat," Journal of Comparative Neurology, vol. 406, no. 4, pp. 503-547, 1999.

[8] J. B. Wang, P. S. Johnson, and Y. Imai, "cDNA cloning of an orphan opiate receptor gene family member and its splice variant," FEBS Letters, vol. 348, no. 1, pp. 75-79, 1994.

[9] M. H. Makman and B. Dvorkin, "Presence of nociceptin (orphanin FQ) receptors in rat retina: comparison with receptors in striatum," European Journal of Pharmacology, vol. 338, no. 2, pp. 171-176, 1997.

[10] M. Dumont and S. Lemaire, "Characterization of the high affinity $[3 \mathrm{H}]$ nociceptin binding site in membrane preparations of rat heart: correlations with the non-opioid dynorphin binding site," Journal of Molecular and Cellular Cardiology, vol. 30, no. 12, pp. 2751-2760, 1998.
[11] M. A. Osinski, M. S. Pampusch, M. P. Murtaugh, and D. R. Brown, "Cloning, expression and functional role of a nociceptin/orphanin FQ receptor in the porcine gastrointestinal tract," European Journal of Pharmacology, vol. 365, no. 2-3, pp. 281-289, 1999.

[12] W. P. Halford, B. M. Gebhardt, and D. J. J. Carr, "Functional role and sequence analysis of a lymphocyte orphan opioid receptor," Journal of Neuroimmunology, vol. 59, no. 1-2, pp. 91-101, 1995.

[13] J. Peluso, K. S. Laforge, H. W. Matthes, M. J. Kreek, B. L. Kieffer, and C. Gavériaux-Ruff, "Distribution of nociceptin/orphanin FQ receptor transcript in human central nervous system and immune cells," Journal of Neuroimmunology, vol. 81, no. 1-2, pp. 184-192, 1998.

[14] M. J. Wick, S. R. Minnerath, S. Roy, S. Ramakrishnan, and H. H. Loh, "Expression of alternate forms of brain opioid 'orphan' receptor mRNA in activated human peripheral blood lymphocytes and lymphocytic cell lines," Molecular Brain Research, vol. 32, no. 2, pp. 342-347, 1995.

[15] J. D. Pomonis, C. J. Billington, and A. S. Levine, "Orphanin FQ, agonist of orphan opioid receptor ORL1, stimulates feeding in rats," NeuroReport, vol. 8, no. 1, pp. 369-371, 1997.

[16] J. Sandin, S. O. Ögren, and L. Terenius, "Nociceptin/orphanin FQ modulates spatial learning via ORL-1 receptors in the dorsal hippocampus of the rat," Brain Research, vol. 997, no. 2, pp. 222-233, 2004.

[17] N. P. Murphy, Y. Lee, and N. T. Maidment, "Orphanin FQ/nociceptin blocks acquisition of morphine place preference," Brain Research, vol. 832, no. 1-2, pp. 168-170, 1999.

[18] R. Ciccocioppo, I. Panocka, C. Polidori, D. Regoli, and M. Massi, "Effect of nociceptin on alcohol intake in alcoholpreferring rats," Psychopharmacology, vol. 141, no. 2, pp. 220224, 1999.

[19] F. Jenck, J. L. Moreau, J. R. Martin et al., "Orphanin FQ acts as an anxiolytic to attenuate behavioral responses to stress," Proceedings of the National Academy of Sciences of the United States of America, vol. 94, no. 26, pp. 14854-14858, 1997.

[20] S. Giuliani, M. Tramontana, A. Lecci, and C. A. Maggi, "Effect of nociceptin on heart rate and blood pressure in anaesthetized rats," European Journal of Pharmacology, vol. 333, no. 2-3, pp. 177-179, 1997.

[21] D. R. Kapusta, S. F. Sezen, J. K. Chang, H. Lippton, and V. A. Kenigs, "Diuretic and antinatriuretic responses produced by the endogenous opioid-like peptide, nociceptin (orphanin FQ)," Life Sciences, vol. 60, no. 1, pp. L-15-L-21, 1996.

[22] A. Fischer, W. G. Forssmann, and B. J. Undem, "Nociceptininduced inhibition of tachykinergic neurotransmission in guinea pig bronchus," Journal of Pharmacology and Experimental Therapeutics, vol. 285, no. 2, pp. 902-907, 1998.

[23] R. L. Mcleod, L. E. Parra, J. C. Mutter et al., "Nociceptin inhibits cough in the guinea-pig by activation of ORL1 receptors," British Journal of Pharmacology, vol. 132, no. 6, pp. 1175-1178, 2001.

[24] S. Giuliani, A. Lecci, M. Tramontana, and C. A. Maggi, "The inhibitory effect of nociceptin on the micturition reflex in anaesthetized rats," British Journal of Pharmacology, vol. 124, no. 7, pp. 1566-1572, 1998.

[25] M. Delgado, D. Pozo, and D. Ganea, "The significance of vasoactive intestinal peptide in immunomodulation," Pharmacological Reviews, vol. 56, no. 2, pp. 249-290, 2004.

[26] E. Gonzalez-Rey, A. Chorny, and M. Delgado, "Regulation of immune tolerance by anti-inflammatory neuropeptides," Nature Reviews Immunology, vol. 7, no. 1, pp. 52-63, 2007. 
[27] E. Gonzalez-Rey, D. Ganea, and M. Delgado, "Neuropeptides: keeping the balance between pathogen immunity and immune tolerance," Current Opinion in Pharmacology, vol. 10, no. 4, pp. 473-481, 2010.

[28] M. S. Pampusch, M. A. Osinski, J. R. Serie, M. P. Murtaugh, and D. R. Brown, "Opioid receptor gene expression in the porcine immune system," Advances in Experimental Medicine and Biology, vol. 437, pp. 59-65, 1998.

[29] M. S. Pampusch, J. R. Serie, M. A. Osinski, V. S. Seybold, M. P. Murtaugh, and D. R. Brown, "Expression of nociceptin/OFQ receptor and prepro-nociceptin/OFQ in lymphoid tissues," Peptides, vol. 21, no. 12, pp. 1865-1870, 2000.

[30] J. Arjomand, S. Cole, and C. J. Evans, "Novel orphanin $\mathrm{FQ} /$ nociceptin transcripts are expressed in human immune cells," Journal of Neuroimmunology, vol. 130, no. 1-2, pp. 100 $108,2002$.

[31] C. N. Serhan, I. M. Fierro, N. Chiang, and M. Pouliot, "Cutting edge: nociceptin stimulates neutrophil chemotaxis and recruitment: Inhibition by aspirin-triggered-15-epilipoxin $\mathrm{A}_{4}$," Journal of Immunology, vol. 166, no. 6, pp. 36503654, 2001.

[32] M. É. Fiset, C. Gilbert, P. E. Poubelle, and M. Pouliot, "Human neutrophils as a source of nociceptin: a novel link between pain and inflammation," Biochemistry, vol. 42, no. 35, pp. 10498-10505, 2003.

[33] B. Buzas, J. Rosenberger, K. W. Kim, and B. M. Cox, "Inflammatory mediators increase the expression of nociceptin/orphanin FQ in rat astrocytes in culture," GLIA, vol. 39, no. 3, pp. 237-246, 2002.

[34] T. R. Miller and A. J. Fulford, "Regulation of nociceptin/orphaninFQ secretion by immune cells and functional modulation of interleukin-2," Peptides, vol. 28, no. 11, pp. 2243-2252, 2007.

[35] S. Trombella, R. Vergura, S. Falzarano, R. Guerrini, G. Calo, and S. Spisani, "Nociceptin/orphanin FQ stimulates human monocyte chemotaxis via NOP receptor activation," Peptides, vol. 26, no. 8, pp. 1497-1502, 2005.

[36] D. E. Kaminsky and T. J. Rogers, "Suppression of CCL2/MCP-1 and CCL5/RANTES expression by nociceptin in human monocytes," Journal of NeuroImmune Pharmacology, vol. 3, no. 2, pp. 75-82, 2008.

[37] O. M. Zack Howard, J. J. Oppenheim, and J. M. Wang, "Chemokines as molecular targets for therapeutic intervention," Journal of Clinical Immunology, vol. 19, no. 5, pp. 280 292, 1999.

[38] D. D. Taub and J. J. Oppenheim, "Chemokines, inflammation and the immune system," Therapeutic Immunology, vol. 1, no. 4, pp. 229-246, 1994.

[39] M. J. Finley, C. M. Happel, D. E. Kaminsky, and T. J. Rogers, "Opioid and nociceptin receptors regulate cytokine and cytokine receptor expression," Cellular Immunology, vol. 252, no. 1-2, pp. 146-154, 2008.

[40] J. Peluso, C. Gavériaux-Ruff, H. W. D. Matthes, D. Filliol, and B. L. Kieffer, "Orphanin FQ/nociceptin binds to functionally coupled ORL1 receptors on human immune cell lines and alters peripheral blood mononuclear cell proliferation," Brain Research Bulletin, vol. 54, no. 6, pp. 655-660, 2001.

[41] P. S. Waits, W. M. Purcell, A. J. Fulford, and J. D. McLeod, "Nociceptin/orphanin FQ modulates human T cell function in vitro," Journal of Neuroimmunology, vol. 149, no. 1-2, pp. 110-120, 2004.

[42] K. H. Easten, R. A. Harry, W. M. Purcell, and J. D. McLeod, "Nociceptin-induced modulation of human T cell function," Peptides, vol. 30, no. 5, pp. 926-934, 2009.
[43] B. Anton, P. Leff, J. J. Meissler et al., "Nociceptin/Orphanin FQ suppresses adaptive immune responses in vivo and at picomolar levels in vitro," Journal of Neuroimmune Pharmacology, vol. 5, no. 1, pp. 143-154, 2010.

[44] L. N. Du, G. C. Wu, and X. D. Cao, "Modulation of orphanin FQ or electroacupuncture (EA) on immune function of traumatic rats," Acupuncture and Electro-Therapeutics Research, vol. 23, no. 1, pp. 1-8, 1998.

[45] Y. Goldfarb, R. K. Reinscheid, and A. W. Kusnecov, "Orphanin FQ/nociceptin interactions with the immune system in vivo: gene expression changes in lymphoid organs and regulation of the cytokine response to staphylococcal enterotoxin A," Journal of Neuroimmunology, vol. 176, no. 12, pp. 76-85, 2006.

[46] H. Zhao, G. C. Wu, and X. D. Cao, "Immunomodulatory activity of orphanin FQ/nociceptin on traumatic rats," Acta Pharmacologica Sinica, vol. 23, no. 4, pp. 343-348, 2002.

[47] H. Zhao, H. W. Huang, G. C. Wu, and X. D. Cao, "Effect of orphanin FQ on interleukin- $1 \beta$ mRNA transcripts in the rat CNS," Neuroscience, vol. 114, no. 4, pp. 1019-1031, 2002.

[48] B. M. Tavares-Murta, M. Zaparoli, R. B. Ferreira et al., "Failure of neutrophil chemotactic function in septic patients," Critical Care Medicine, vol. 30, no. 5, pp. 1056-1061, 2002.

[49] R. S. Hotchkiss and I. E. Karl, "The pathophysiology and treatment of sepsis," New England Journal of Medicine, vol. 348, no. 2, pp. 138-150, 2003.

[50] J. C. Alves-Filho, A. De Freitas, M. Russo, and F. Q. Cunha, "Toll-like receptor 4 signaling leads to neutrophil migration impairment in polymicrobial sepsis," Critical Care Medicine, vol. 34, no. 2, pp. 461-470, 2006.

[51] J. C. Alves-Filho, C. Benjamim, B. M. Tavares-Murta, and F. Q. Cunha, "Failure of neutrophil migration toward infectious focus in severe sepsis: a critical event for the outcome of this syndrome," Memorias do Instituto Oswaldo Cruz, vol. 100, no. 1, pp. 223-226, 2005.

[52] H. K. De Jong, T. Van Der Poll, and W. J. Wiersinga, "The systemic pro-inflammatory response in sepsis," Journal of Innate Immunity, vol. 2, no. 5, pp. 422-430, 2010.

[53] R. C. Reddy and T. J. Standiford, "Effects of sepsis on neutrophil chemotaxis," Current Opinion in Hematology, vol. 17, no. 1, pp. 18-24, 2010.

[54] D. C. Nascimento, J. C. Alves-Filho, F. Sônego et al., "Role of regulatory $\mathrm{T}$ cells in long-term immune dysfunction associated with severe sepsis," Critical Care Medicine, vol. 38, no. 8, pp. 1718-1725, 2010.

[55] D. Carvalho, F. Petronilho, F. Vuolo et al., "The nociceptin/orphanin FQ-NOP receptor antagonist effects on an animal model of sepsis," Intensive care medicine, vol. 34, no. 12, pp. 2284-2290, 2008.

[56] J. P. Williams, J. P. Thompson, S. P. Young et al., "Nociceptin and urotensin-II concentrations in critically ill patients with sepsis," British Journal of Anaesthesia, vol. 100, no. 6, pp. 810814, 2008.

[57] A. Serrano-Gomez, J. P. Thompson, and D. G. Lambert, "Nociceptin/orphanin FQ in inflammation and sepsis," British journal of anaesthesia, vol. 106, no. 1, pp. 6-12, 2011.

[58] U. M. Stamer, M. Book, C. Comos, L. Zhang, F. Nauck, and F. Stüber, "Expression of the nociceptin precursor and nociceptin receptor is modulated in cancer and septic patients," British Journal of Anaesthesia, vol. 106, no. 4, pp. 566-572, 2011.

[59] S. Kato, Y. Tsuzuki, R. Hokari et al., "Role of nociceptin/ orphanin FQ (Noc/oFQ) in murine experimental colitis," 
Journal of Neuroimmunology, vol. 161, no. 1-2, pp. 21-28, 2005.

[60] P. L. McGeer and E. G. McGeer, "Inflammation and neurodegeneration in Parkinson's disease," Parkinsonism and Related Disorders, vol. 10, no. 1, pp. S3-S7, 2004.

[61] M. G. Tansey, M. K. McCoy, and T. C. Frank-Cannon, "Neuroinflammatory mechanisms in Parkinson's disease: potential environmental triggers, pathways, and targets for early therapeutic intervention," Experimental Neurology, vol. 208, no. 1, pp. 1-25, 2007.

[62] J. K. Lee, T. Tran, and M. G. Tansey, "Neuroinflammation in Parkinson's disease," Journal of Neuroimmune Pharmacology, vol. 4, no. 4, pp. 419-429, 2009.

[63] R. M. Ransohoff and V. H. Perry, "Microglial physiology: unique stimuli, specialized responses," Annual Review of Immunology, vol. 27, pp. 119-145, 2009.

[64] D. Blum-Degena, T. Müller, W. Kuhn, M. Gerlach, H. Przuntek, and P. Riederer, "Interleukin- $1 \beta$ and interleukin-6 are elevated in the cerebrospinal fluid of Alzheimer's and de novo Parkinson's disease patients," Neuroscience Letters, vol. 202, no. 1-2, pp. 17-20, 1995.

[65] R. J. Dobbs, A. Charlett, A. G. Purkiss, S. M. Dobbs, C. Weller, and D. W. Peterson, "Association of circulating TNF$\alpha$ and IL-6 with ageing and parkinsonism," Acta Neurologica Scandinavica, vol. 100, no. 1, pp. 34-41, 1999.

[66] K. Hisanaga, M. Asagi, Y. Itoyama, and Y. Iwasaki, "Increase in peripheral CD4 bright+ CD8 dull+ T cells in Parkinson disease," Archives of Neurology, vol. 58, no. 10, pp. 1580-1583, 2001.

[67] M. Rentzos, C. Nikolaou, E. Andreadou et al., "Circulating interleukin-15 and RANTES chemokine in Parkinson's disease," Acta Neurologica Scandinavica, vol. 116, no. 6, pp. 374379, 2007.

[68] E. C. Hirsch and S. Hunot, "Neuroinflammation in Parkinson's disease: a target for neuroprotection?" The Lancet Neurology, vol. 8, no. 4, pp. 382-397, 2009.

[69] L. Qian, P. M. Flood, and J. S. Hong, "Neuroinflammation is a key player in Parkinson's disease and a prime target for therapy," Journal of Neural Transmission, vol. 117, no. 8, pp. 971-979, 2010.

[70] M. Marti, F. Mela, C. Veronesi et al., "Blockade of nociceptin/orphanin FQ receptor signaling in rat substantia nigra pars reticulata stimulates nigrostriatal dopaminergic transmission and motor behavior," Journal of Neuroscience, vol. 24, no. 30, pp. 6659-6666, 2004.

[71] M. Marti, F. Mela, M. Fantin et al., "Blockade of nociceptin/orphanin FQ transmission attenuates symptoms and neurodegeneration associated with Parkinson's disease," Journal of Neuroscience, vol. 25, no. 42, pp. 9591-9601, 2005.

[72] N. P. Visanji, R. M. A. de Bie, T. H. Johnston, A. C. McCreary, J. M. Brotchie, and S. H. Fox, "The nociceptin/orphanin FQ (NOP) receptor antagonist J-113397 enhances the effects of levodopa in the MPTP-lesioned nonhuman primate model of Parkinson's disease," Movement Disorders, vol. 23, no. 13, pp. 1922-1925, 2008.

[73] R. Viaro, R. Sanchez-Pernaute, M. Marti, C. Trapella, O. Isacson, and M. Morari, "Nociceptin/orphanin FQ receptor blockade attenuates MPTP-induced parkinsonism," Neurobiology of Disease, vol. 30, no. 3, pp. 430-438, 2008.

[74] O. S. Mabrouk, M. Marti, and M. Morari, "Endogenous nociceptin/orphanin FQ (N/OFQ) contributes to haloperidolinduced changes of nigral amino acid transmission and parkinsonism: a combined microdialysis and behavioral study in naïve and nociceptin/orphanin FQ receptor knockout mice," Neuroscience, vol. 166, no. 1, pp. 40-48, 2010.

[75] M. Volta, O. S. Mabrouk, S. Bido, M. Marti, and M. Morari, "Further evidence for an involvement of nociceptin/orphanin FQ in the pathophysiology of Parkinson's disease: a behavioral and neurochemical study in reserpinized mice," Journal of Neurochemistry, vol. 115, no. 6, pp. 1543-1555, 2010.

[76] M. Marti, S. Sarubbo, F. Latini et al., "Brain interstitial nociceptin/orphanin FQ levels are elevated in Parkinson's disease," Movement Disorders, vol. 25, no. 11, pp. 1723-1732, 2010.

[77] C. Acosta and A. Davies, "Bacterial lipopolysaccharide regulates nociceptin expression in sensory neurons," Journal of Neuroscience Research, vol. 86, no. 5, pp. 1077-1086, 2008.

[78] C. Zhang and J. J. McDougall, "Stimulation of sensory neuropeptide release by nociceptin/orphanin FQ leads to hyperaemia in acutely inflamed rat knees," British Journal of Pharmacology, vol. 148, no. 7, pp. 938-946, 2006.

[79] T. Kimura, K. Kitaichi, K. Hiramatsu et al., "Intradermal application of nociceptin increases vascular permeability in rats: the possible involvement of histamine release from mast cells," European Journal of Pharmacology, vol. 407, no. 3, pp. 327-332, 2000.

[80] Z. L. S. Brookes, E. N. Stedman, R. Guerrini, B. K. Lawton, G. Calo, and D. G. Lambert, "Proinflammatory and vasodilator effects of nociceptin/orphanin FQ in the rat mesenteric microcirculation are mediated by histamine," American Journal of Physiology, vol. 293, no. 5, pp. H2977H2985, 2007.

[81] T. Andoh, Y. Yageta, H. Takeshima, and Y. Kuraishi, "Intradermal nociceptin elicits itch-associated responces through leukotriene B4 in mice," Journal of Investigative Dermatology, vol. 123, no. 1, pp. 196-201, 2004.

[82] K. Fukuda, T. Shoda, H. Morikawa, S. Kato, and K. Mori, "Activation of mitogen-activated protein kinase by the nociceptin receptor expressed in Chinese hamster ovary cells," FEBS Letters, vol. 412, no. 2, pp. 290-294, 1997.

[83] B. E. Hawes, M. P. Graziano, and D. G. Lambert, "Cellular actions of nociceptin: transduction mechanisms," Peptides, vol. 21, no. 7, pp. 961-967, 2000.

[84] A. M. F. Liu and Y. H. Wong, "Mu-Opioid receptor-mediated phosphorylation of $\mathrm{I} \kappa \mathrm{B}$ kinase in human neuroblastoma SHSY5Y cells," NeuroSignals, vol. 14, no. 3, pp. 136-142, 2005.

[85] C. L. Donica, V. I. Ramirez, H. O. Awwad, N. T. Zaveri, L. Toll, and K. M. Standifer, "Orphanin FQ/Nociceptin Activates Nuclear Factor Kappa B," Journal of Neuroimmune Pharmacology, vol. 6, no. 4, pp. 617-625, 2011.

[86] M. Connor, A. Yeo, and G. Henderson, "The effect of nociceptin on $\mathrm{Ca} 2+$ channel current and intracellular $\mathrm{Ca} 2+$ in the SH-SY5Y human neuroblastoma cell line," British Journal of Pharmacology, vol. 118, no. 2, pp. 205-207, 1996.

[87] H. Matthes, E. P. Seward, B. Kieffer, and R. A. North, "Functional selectivity of orphanin FQ for its receptor coexpressed with potassium channel subunits in Xenopus laevis oocytes," Molecular Pharmacology, vol. 50, no. 3, pp. 447-450, 1996.

[88] J. C. Meunier, "Nociceptin/orphanin FQ and the opioid receptor-like ORL1 receptor," European Journal of Pharmacology, vol. 340, no. 1, pp. 1-15, 1997.

[89] J. S. C. Chan, L. Y. Yung, J. W. M. Lee, Y. L. Wu, G. Pei, and Y. H. Wong, "Pertussis toxin-insensitive signaling of the ORL1 receptor: coupling to G(z) and G16 proteins," Journal of Neurochemistry, vol. 71, no. 5, pp. 2203-2210, 1998. 
[90] D. C. New and Y. H. Wong, "The ORL1 receptor: molecular pharmacology and signalling mechanisms," NeuroSignals, vol. 11, no. 4, pp. 197-212, 2002.

[91] L. G. Lou, L. Ma, and G. Pei, "Nociceptin/Orphanin FQ activates protein kinase $\mathrm{C}$, and this effect is mediated through phospholipase $\mathrm{C} / \mathrm{Ca} 2+$ pathway," Biochemical and Biophysical Research Communications, vol. 240, no. 2, pp. 304-308, 1997.

[92] W. M. Armstead, "Differential activation of ERK, p38, and JNK MAPK by nociceptin/orphanin FQ in the potentiation of prostaglandin cerebrovasoconstriction after brain injury," European Journal of Pharmacology, vol. 529, no. 1-3, pp. 129$135,2006$.

[93] B. E. Hawes, S. Fried, X. Yao, B. Weig, and M. P. Graziano, "Nociceptin (ORL-1) and $\mu$-opioid receptors mediate mitogen-activated protein kinase activation in $\mathrm{CHO}$ cells through a G(i)-coupled signaling pathway: Evidence for distinct mechanisms of agonist-mediated desensitization," Journal of Neurochemistry, vol. 71, no. 3, pp. 1024-1033, 1998.

[94] L. M. Harrison and D. K. Grandy, "Opiate modulating properties of nociceptin/orphanin FQ," Peptides, vol. 21, no. 1, pp. 151-172, 2000.

[95] E. H. T. Wu, R. K. H. Lo, and Y. H. Wong, "Regulation of STAT3 activity by G16-coupled receptors," Biochemical and Biophysical Research Communications, vol. 303, no. 3, pp. 920-925, 2003.

[96] J. S. Mogil and G. W. Pasternak, "The molecular and behavioral pharmacology of the orphanin FQ/nociceptin peptide and receptor family," Pharmacological Reviews, vol. 53, no. 3, pp. 381-415, 2001.

[97] L. F. Chuang, T. K. Chuang Jr., K. F. Killam et al., "Expression of kappa opioid receptors in human and monkey lymphocytes," Biochemical and Biophysical Research Communications, vol. 209, no. 3, pp. 1003-1010, 1995.

[98] J. P. Williams, J. P. Thompson, J. McDonald et al., "Human peripheral blood mononuclear cells express nociceptin/ orphanin FQ, but not $\mu \delta$, or $\kappa$ opioid receptors," Anesthesia and Analgesia, vol. 105, no. 4, pp. 998-1005, 2007.

[99] N. Sitte, M. Busch, S. A. Mousa et al., "Lymphocytes upregulate signal sequence-encoding proopiomelanocortin mRNA and beta-endorphin during painful inflammation in vivo," Journal of Neuroimmunology, vol. 183, no. 1-2, pp. 133145, 2007.

[100] P. D. Lyons and J. E. Blalock, "Pro-opiomelanocortin gene expression and protein processing in rat mononuclear leukocytes," Journal of Neuroimmunology, vol. 78, no. 1-2, pp. 4756, 1997.

[101] M. Verma-Gandhu, E. F. Verdu, D. Cohen-Lyons, and S. M. Collins, "Lymphocyte-mediated regulation of $\beta$-endorphin in the myenteric plexus," American Journal of Physiology, vol. 292, no. 1, pp. G344-G348, 2007.

[102] D. Labuz, Y. Schmidt, A. Schreiter, H. L. Rittner, S. A. Mousa, and H. Machelska, "Immune cell-derived opioids protect against neuropathic pain in mice," Journal of Clinical Investigation, vol. 119, no. 2, pp. 278-286, 2009, Erratum in: The Journal of Clinical Investigation, vol. 119, no. 4, pp. 1051, 2009.

[103] H. Machelska and C. Stein, "Leukocyte-derived opioid peptides and inhibition of pain," Journal of Neuroimmune Pharmacology, vol. 1, no. 1, pp. 90-97, 2006.

[104] C. Börner, R. Stumm, V. Höllt, and J. Kraus, "Comparative analysis of mu-opioid receptor expression in immune and neuronal cells," Journal of Neuroimmunology, vol. 188, no. 12, pp. 56-63, 2007.

[105] J. Kraus, C. Börner, E. Giannini et al., "Regulation of $\mu$-opioid receptor gene transcription by interleukin-4 and influence of an allelic variation within a STAT6 transcription factor binding site," Journal of Biological Chemistry, vol. 276, no. 47, pp. 43901-43908, 2001.

[106] J. Wybran, T. Appelboom, J. P. Famaey, and A. Govaerts, "Suggestive evidence for receptors for morphine and methionine-enkephalin on normal human blood T lymphocytes," Journal of Immunology, vol. 123, no. 3, pp. 1068-1070, 1979.

[107] B. M. Sharp, W. F. Keane, and H. J. Suh, "Opioid peptides rapidly stimulate superoxide production by human polymorphonuclear leukocytes and macrophages," Endocrinology, vol. 117, no. 2, pp. 793-795, 1985.

[108] H. M. Johnson, E. M. Smith, B. A. Torres, and J. E. Blalock, "Regulation of the in vitro antibody response by neuroendocrine hormones," Proceedings of the National Academy of Sciences of the United States of America, vol. 79, no. 13, pp. 4171-4174, 1982.

[109] T. K. Eisenstein and M. E. Hilburger, "Opioid modulation of immune responses: effects on phagocyte and lymphoid cell populations," Journal of Neuroimmunology, vol. 83, no. 1-2, pp. 36-44, 1998.

[110] H. H. Hussey and S. Katz, "Infections resulting from narcotic addiction. Report of 102 cases," The American Journal of Medicine, vol. 9, no. 2, pp. 186-193, 1950.

[111] G. Wei, J. Moss, and C. S. Yuan, "Opioid-induced immunosuppression: is it centrally mediated or peripherally mediated?" Biochemical Pharmacology, vol. 65, no. 11, pp. 17611766, 2003.

[112] D. P. Devine, S. J. Watson, and H. Akil, "Nociceptin/orphanin FQ regulates neuroendocrine function of the limbic-hypothalamic-pituitary-adrenal axis," Neuroscience, vol. 102, no. 3, pp. 541-553, 2001.

[113] M. K. Green, E. V. Barbieri, B. D. Brown, K. W. Chen, and D. P. Devine, "Roles of the bed nucleus of stria terminalis and of the amygdala in N/OFQ-mediated anxiety and HPA axis activation," Neuropeptides, vol. 41, no. 6, pp. 399-410, 2007.

[114] J. D. Leggett, K. L. Dawe, D. S. Jessop, and A. J. Fulford, "Endogenous nociceptin/orphanin fq system involvement in hypothalamic-pituitary-adrenal axis responses: relevance to models of inflammation," Journal of Neuroendocrinology, vol. 21, no. 11, pp. 888-897, 2009. 

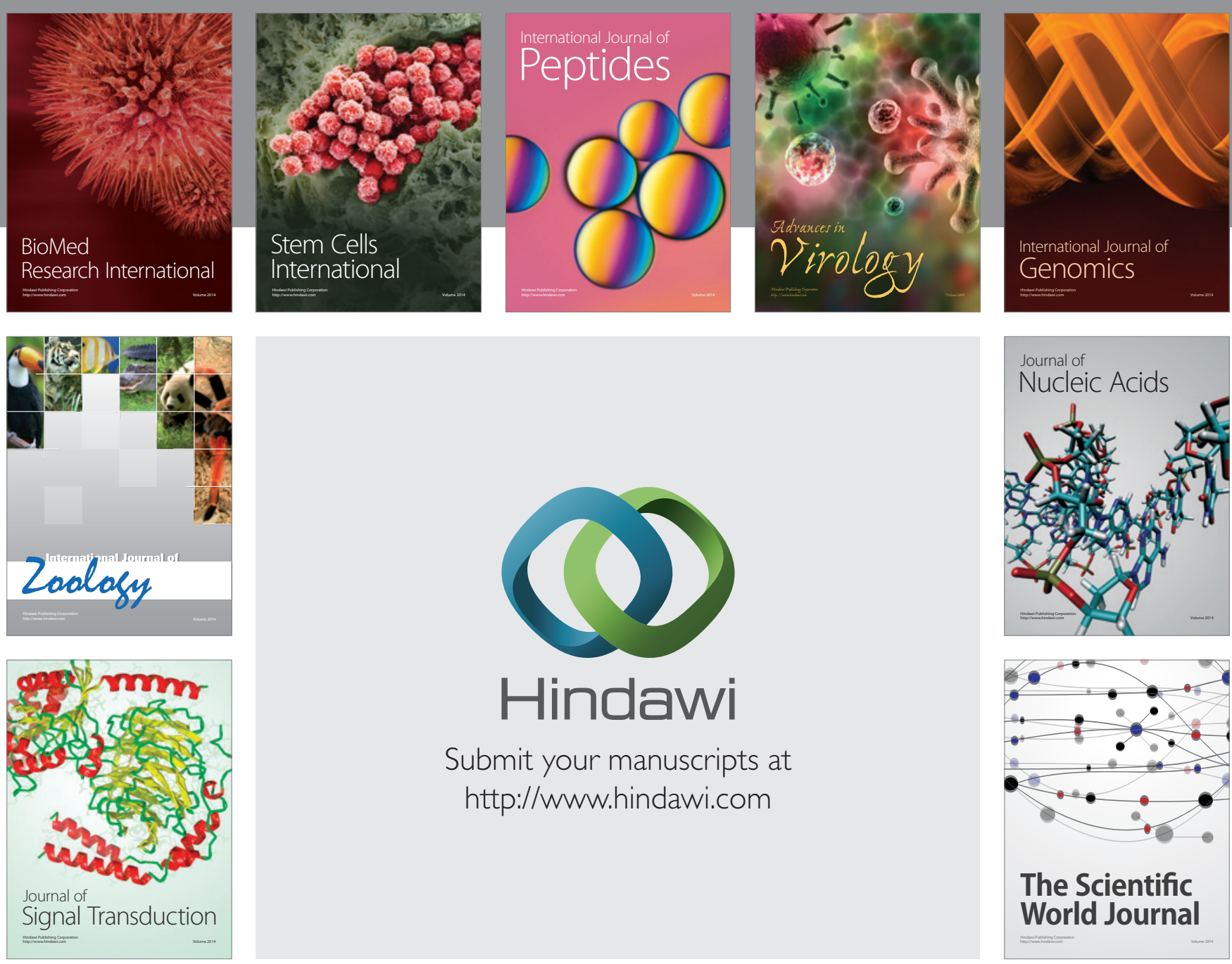

Submit your manuscripts at

http://www.hindawi.com
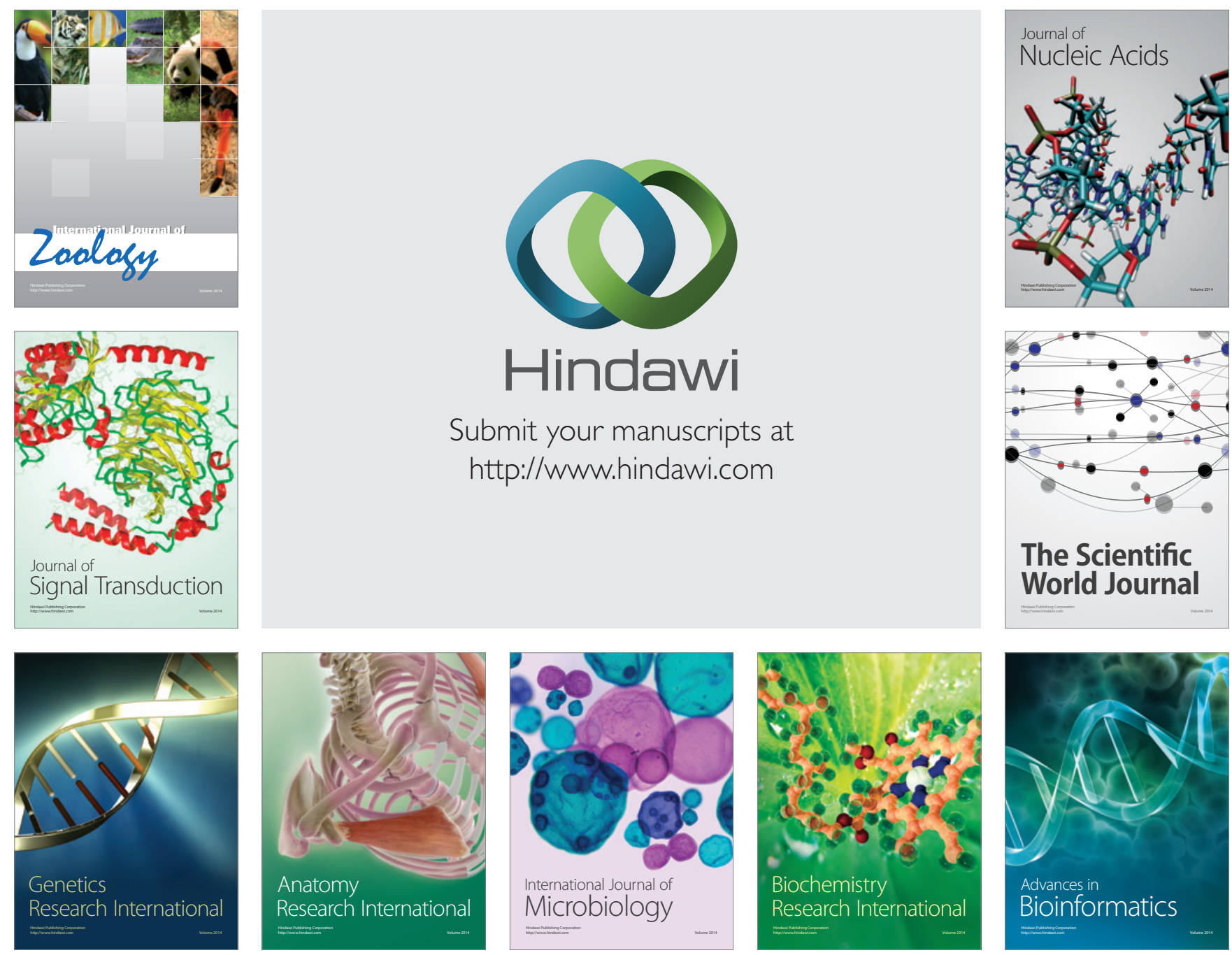

The Scientific World Journal
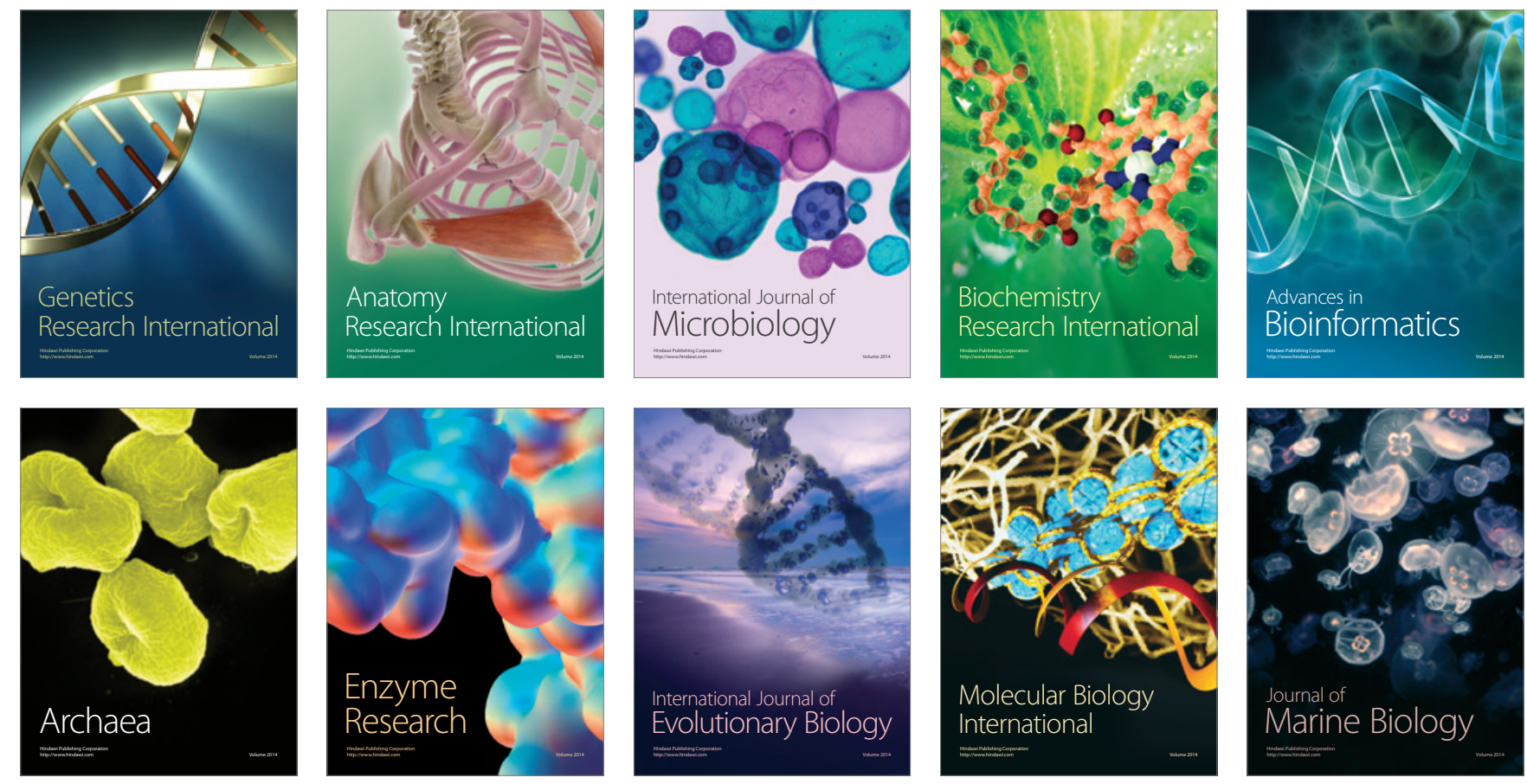